American Journal of Infectious Diseases 7 (1): 1-7, 2011

ISSN 1553-6203

(C) 2011 Science Publications

\title{
Comparative Study of Antibacterial Susceptibility Patterns of the Bacteria Isolated from Patients' Blood Samples over Two Periods
}

\author{
Aziz Japoni, Mehdi Kalani, Abdolvahab Alborzi, \\ Sara Japoni and Noradin Rafaatpour \\ Clinical Microbiology Research Center, \\ Shiraz University of Medical Sciences, Shiraz, Iran
}

\begin{abstract}
Problem statement: Due to continuous changes in the frequencies and antibacterial susceptibility patterns of nosocomial pathogens, periodical surveillance of these fluctuations could help the clinicians to treat hospitalized patients more efficiently whenever empirical therapies need to be considered. This study was conducted to compare the prevalence of the bacteria recovered from bloodstream samples by Bactec 9240, over the two periods of 2001-2004 and 2005-2008 and to evaluate their antibacterial susceptibility patterns. Approach: Totally, 3622 culture positive blood samples were analyzed over the periods. Antibacterial susceptibility patterns of the isolates were determined by standard disk diffusion (Kirby-Bauer) method. The data were compared in terms of quantity and quality of the pathogens and based on their distributions in three main wards. Results: Changes were observed in bacterial composition and frequencies of them, between the two periods. Compared with the first pried, increased frequencies of antibiotic resistant bacteria such as $S$. aureus, enterococci, acintobacter and pseudomonas were noticed in the second period. Most patients were admitted to pediatrics, followed by adults and neonates wards. Increased antibiotic resistance of the majority of the bacteria in the second period indicates the decreased efficacy of corresponding antibiotics. However, overall efficacy of some antibiotics such as ciprofloxacin and amikacin against Gram positive bacteria preserved. Conclusion: Trend of composition of the bacteria from first to second period could suggest the domination of antibiotic resistant bacteria over the sensitive ones. Appropriate strategies including strict control measures and rational prescription of the effective antibiotics may retard the trend accordingly. Vancomycin and imipenem were the most active antibiotics against Gram positive and negative bacteria. Combination of these two antibiotics is highly recommended for empirical therapy.
\end{abstract}

Key words: Comparative study, blood samples, antibiotic resistance, control measures, antibacterial susceptibility patterns, S. aureus, standard disk diffusion, Methicillin Resistant S. aureus (MRSA), Pseudomonas aeruginosa

\section{INTRODUCTION}

Rapid and reliable detection of microorganisms from the blood is one of the most critical functions of a diagnostic microbiology laboratory. It is well known that the isolation of microorganisms is a gold standard for accurate detection of etiological agents of infectious diseases (Paolucci et al., 2010). Furthermore, early detection of bloodstream infections could prevent implantation of microorganisms into vital organs such as the brain, heart or kidneys (Bakowski et al., 2008). To detect blood infections, different techniques and instruments have been innovated. One of such detection systems is bactec, which is widely accepted as a rapid and accurate method for the detection of bloodstream infections (Cermak et al., 2011). In this study, blood samples were processed in bactec 9240 (Becton Dickinson Diagnostic Instrument Systems, Sparks, Md.). This system is noninvasive and automated blood culture systems with continuous monitoring have introduced a technology that reduces the time needed to detect positive blood cultures as well as decreases the specimen handling (Kim and Han, 2010; Bert et al., 2010).

The purpose of this study was to compare the frequencies and antibacterial susceptibility patterns of the bacteria isolated from blood samples of the hospitalized patients during two four year periods, using bactec 9240. Hopefully, this comparison can help

Corresponding Author: Aziz Japoni, Clinical Microbiology Research Center, Shiraz University of Medical Sciences,

Post code: 71037-11351, Shiraz, Iran Tel: +98-711-6474264 Fax: +98-711- 6474303 
adopt a new strategy to prevent the emerging antibiotic resistant isolates in the hospitals. Prediction of the predominant bacteria and determination of the effective clinical antibiotic therapy can help promote the treatment and save on the patient's management.

\section{MATERIALS AND METHODS}

This study was conducted to compare the bacteria isolated from blood samples over the two periods, 2001-2004 and 2005-2008, at Nemazee Hospital, affiliated with Shiraz University of Medical Sciences, Shiraz, southern Iran. This hospital is a tertiary care facility with 1000 beds and located in Fars province. Suspicious patients to blood infections admitted to three main hospital wards including, neonates, pediatrics and adults were enrolled in the study. Ten and $3 \mathrm{ml}$ blood samples from pediatric/neonate and adult patients were taken under the supervision of specialized physician and inoculated to bactec bottles peds plus/ $\mathrm{F}$ or adult plus aerobic/F, aseptically. An indication for patient blood infection was confirmed by the specialized physician in each ward.

The bottles were incubated in bactec system, as recommended by the manufacturer for 7 consecutive days. The negative bottles were then removed from the instrument. During the seven day incubation, when system alerted for positive results, 3-5 drops of blood culture samples taken with $1 \mathrm{ml}$ sterile syringe, were inoculated on the blood and chocolate agars containing $5 \%$ whole sheep blood and then incubated aerobically at $37^{\circ} \mathrm{C}$ overnight. The pure cultures were then stained by Gram's method. Identification of bacteria in positive cultures was carried out according to standard biochemical tests and subcultuing to appropriate media.

Sensitivity of identified bacteria to the different antibiotics was determined, according to standard disk diffusion (Kirby-Bauer) method using Mast Co (Mast Co, Merseyside, UK) or Difco (BBL, USA) disks. E. coli (ATCC 25922) and S. aureus (ATCC 25923) were used as the control for antibiotic susceptibility determination. Antibacterial susceptibility was interpreted as recommended by National Committee for Clinical Laboratory Standards NCCLS (National Committee for Clinical Laboratory Standards).

Difference in frequency of bacteria over the two periods of study was analyzed by Chi-square (SPSS version 15 software) and Fisher's exact tests. The significant level was defined as $\mathrm{p}<0.05$.

\section{RESULTS}

During the periods 2001-4 and 2005-8, 9407 and 10400 blood specimens were received and processed, of which $1122(11.9 \%)$ and 2500 (24\%) were grown in bactec apparatus, respectively. Totally, from 19807 blood samples, 3622 (18.2\%) were positive during the whole periods of the study. Seven top list isolated bacteria from the blood samples were as follows: coagulase negative staphylococci, Staphylococcus aureus, E.coli, Pseudomonas aeruginosa, bacillus spp, enterobacter spp and acinetobacter spp. Coagulase negative staphylococci and bacillus spp, are normal flora of the skin and the possibility of blood samples contamination with them during sampling should be considered. Fluctuation in frequencies of some important pathogenic isolates such as Pseudomonas aeruginosa, acinetobacter spp, enterococci spp and brucella spp. was statistically significant. Staphylococcus aureus and E.coli were Gram positive and Gram negative true pathogenic microorganisms, isolated from the patients with the highest frequencies. As shown in Table 1, during the 8 year period of study some bacteria such as fusobacter, Neissieria menigitidis, peptococci, Listeria monocytogrenes, campylobacter spp and hafnia were isolated at very low quantities $(1 ; 0.1 \%)$. Comparison of fluctuation in antibiotic resistance of the Gram negative and Gram positive bacteria indicates that in the second period (2005-8), bacteria acquired more resistance to the tested antibiotic, compared to the first period (2001-4). This finding for some bacteria such as: acinetobacter, Pseudomonas aeuroginosa. S. aureus and entrococci spp were remarkable. Table 2 and 3 present the detailed comparison of bacterial resistance patterns over the two periods. Comparison of the isolates from the patients admitted to the three above-mentioned wards, revealed that frequencies (\%) of bacteria in the patients with bloodstream infections in pediatrics ward was higher, compared to the other two wards (Table 4). Changes in frequencies of some bacteria such as $S$. aureus, E.coli, $P$. aeruginosa and brucella spp were statistically significant. Reduced efficacy of the antibiotics against Gram positive bacteria was observed in the second period, while for Gram negative bacteria the efficacy of majority of antibiotics preserved. Overall reduction of in vitro activity of cephalexin and clindamycin against Gram negative and ceftazidime against Gram positive bacteria was considerable. Figure 1 and 2 illustrate the changes in sensitivity of Gram negative and positive bacteria to the five effective antibiotics during the periods of investigation. 
Am. J. Infect. Dis., 7 (1): 1-7, 2011

Table 1: Frequencies of isolated microorganisms from bactec 9240 over the periods 2001-2004 and 2005-2008

\begin{tabular}{|c|c|c|c|}
\hline Microorganisms & Total Frequency 2001-2004 (\%) & Total Frequency 2005-2008(\%) & $P$ value \\
\hline *Coagulase Negative Staphylococci & $523(47)$ & $1295(51.8)$ & 0.09 \\
\hline Staphylococcus aureus & 132 (12) & $250(10)$ & 0.15 \\
\hline E.coli & $64(6)$ & $112(4.5)$ & 0.13 \\
\hline Pseudomonas aeruginosa & $52(4.5)$ & $50(2.0)$ & 0.000018 \\
\hline Bacillus spp & $52(4.5)$ & $60(2.4)$ & 0.0005 \\
\hline Enterobacter spp. & $50(4)$ & $70(2.8)$ & 0.012 \\
\hline Acinetobacter spp. & $40(3.5)$ & $165(6.6)$ & 0.00005 \\
\hline Streptococcus viridans & $34(3)$ & $45(1.8)$ & 0.022 \\
\hline Enterococcus spp. & $29(2.5)$ & $115(4.6)$ & 0.005 \\
\hline Klebsiella spp. & $29(2.5)$ & $55(2.2)$ & 0.49 \\
\hline Brucella spp. & $28(2.4)$ & $20(0.8)$ & 0.00005 \\
\hline Streptococcus pneumoniae & $20(1.6)$ & 23(0.9) & 0.029 \\
\hline *Diphteroid & $16(1.3)$ & $70(2.8)$ & 0.014 \\
\hline cedecia davisae & $12(0.46)$ & NA & \\
\hline Salmonella spp. & $11(1)$ & $5(0.2)$ & 0.001 \\
\hline Haemophilus influenzae. & $8(0.8)$ & $15(0.60$ & 0.7 \\
\hline Candida spp & $6(0.6)$ & $30(1.2)$ & 0.064 \\
\hline Proteus spp & $5(0.5)$ & - & NA \\
\hline Oligella spp & $4(0.4)$ & $30(1.2)$ & 0.015 \\
\hline Morganella & - & $4(0.16)$ & NA \\
\hline *Micrococcus spp & $3(0.3)$ & $10(0.4)$ & $0.75^{*}$ \\
\hline Streptococcus spp. & $3(0.3)$ & $25(1.0)$ & 0.02 \\
\hline Serratia spp & $3(0.3)$ & $25(1.0)$ & 0.02 \\
\hline Gram positive anaerobic org & $2(0.2)$ & - & NA \\
\hline Gram negative rod & $2(0.2)$ & $5(0.2)$ & $1^{*}$ \\
\hline Nocardia & - & $2(0.08)$ & NA \\
\hline Citrobacter & - & $2(0.08)$ & NA \\
\hline Morexella & - & $2(0.08)$ & NA \\
\hline Fusobacter & $1(0.1)$ & - & NA \\
\hline Neissieria menigitidis & $1(0.1)$ & - & NA \\
\hline b hemolytic sterp group $A \& B$ & $1(0.1)$ & $2(0.8)$ & $1^{*}$ \\
\hline Peptococci & - & $1(0.04)$ & NA \\
\hline Listeria monocytogrenes & $1(0.1)$ & - & NA \\
\hline Campylobacter spp & $1(0.1)$ & - & NA \\
\hline Hafnia & $1(0.1)$ & - & NA \\
\hline Total & $1122(100)$ & $2500(100)$ & NA \\
\hline
\end{tabular}

*: Analyzed with Fisher's exact tests. Significant values are printed in bold

Table 2: Comparison of antibiotic resistance patterns of important Gram negative bacteria recovered from bactec 9240 over periods 2001-4 and 2005-8

\begin{tabular}{|c|c|c|c|c|c|c|c|c|c|c|c|c|c|c|c|}
\hline \multirow[b]{2}{*}{ Bacteria } & \multirow{2}{*}{$\begin{array}{l}\text { Period: a or b: } \\
\text { frequency }\end{array}$} & \multicolumn{14}{|c|}{ Percentage of antibiotic resistance } \\
\hline & & GM & $\mathrm{CN}$ & SXT & CXM & $\mathrm{CRO}$ & IMI & CIP & AK & CAZ & AP & CPM & $\mathrm{C}$ & CFM & CTX \\
\hline \multirow[t]{2}{*}{ Acinetobacter spp } & a: 40 & 17 & 39 & 38.00 & ND & ND & ND & 17 & 41 & 39 & ND & ND & ND & ND & ND \\
\hline & b: 165 & 46 & 74.6 & 43.50 & 82 & 47 & 32.5 & 17 & 25 & 48 & 86.7 & ND & 45.7 & 85.7 & 62.5 \\
\hline \multirow[t]{2}{*}{ E. coli } & a: 64 & 4.5 & 53.3 & 76.00 & 37.9 & ND & 2.5 & 16.8 & 9.1 & 24 & 74 & ND & ND & ND & ND \\
\hline & b: 112 & 57 & 78 & 75.50 & 63.5 & 64.5 & 0 & 45 & 17 & 47.5 & 98 & 48.6 & 72 & 65.9 & 71 \\
\hline \multirow[t]{2}{*}{ Pseudomonas spp } & a: 52 & 24.3 & ND & 93.80 & 100 & ND & ND & 10.8 & ND & ND & ND & ND & ND & ND & ND \\
\hline & b: 50 & 33.3 & 81 & 81.00 & 95 & 58 & 12.5 & 26 & 17 & 41.5 & 87 & 43.5 & 75 & 91 & ND \\
\hline \multirow[t]{2}{*}{ Enterobacter } & a: 50 & ND & ND & 39.00 & 44 & ND & 0 & ND & 11 & 54 & 78 & ND & ND & ND & ND \\
\hline & b: 70 & 42.5 & 78.7 & 31.66 & 68.7 & 66 & 0 & 14.5 & 26 & 52.4 & 86 & 50 & 41 & 65.5 & 59.5 \\
\hline \multirow[t]{2}{*}{ Klebsiella spp } & a: 29 & 23.5 & 28.6 & 26.60 & 18.2 & ND & 16.7 & 9.1 & 26.8 & 54 & 36.4 & ND & ND & ND & ND \\
\hline & b: 55 & 42 & 60 & 53.00 & 80 & 56 & 0 & 33 & 24 & 58 & 95 & 38 & 55.5 & ND & ND \\
\hline \multirow[t]{2}{*}{ Salmonella spp } & a: 11 & 11 & 0 & 11.00 & ND & ND & 0 & 0 & ND & 6 & ND & ND & ND & ND & ND \\
\hline & b: 5 & 0 & 20 & 33.30 & ND & 20 & 0 & 0 & 0 & 0 & ND & 0 & 0 & ND & 25 \\
\hline \multirow[t]{2}{*}{ Brucella spp } & a: 28 & 10 & 80 & 44.50 & ND & 25 & 0 & 10 & 16.7 & 66.7 & 33.3 & ND & ND & ND & ND \\
\hline & b: 20 & 0 & 62.5 & 50.00 & 25 & 5.5 & 0 & 0 & 0 & 31.5 & ND & ND & ND & ND & ND \\
\hline Haemophilus & a: 8 & 6 & 25 & 38.00 & 25 & 9 & 0 & 5.2 & 6 & 15 & 25 & 5.3 & 15 & 16 & 15 \\
\hline influenzae & b: 15 & 11.1 & 33.3 & 44.40 & 35 & 11.1 & 0 & 11.1 & 11.1 & 22.2 & 33.3 & 11.1 & ND & 22.2 & 22.2 \\
\hline
\end{tabular}

Period a: 2001-2004; Period b: 2005-2008, Abbreviations: GM; gentamicin, CN: cephalexin, SXT; co-trimoxazole, CXM; ceforaxime, IMI; imipenem, CIP; ciprofloxacin, Ak; amikacin, CAZ; ceftazidime, AP; ampicillin, CPM, cefepeme, C; chloramphenicol , CFM; cefixime, CTX; cefotaxime, ND; not determined 
Am. J. Infect. Dis., 7 (1): 1-7, 2011

Table 3: Comparison of antibiotic resistance patterns of important Gram positive bacteria recovered from bactec 9240 over the periods $2001-4$ and 2005-8

\begin{tabular}{|c|c|c|c|c|c|c|c|c|}
\hline \multirow[b]{2}{*}{ Bacteria } & \multirow{2}{*}{$\begin{array}{l}\text { Period: a or b: } \\
\text { frequency }\end{array}$} & \multicolumn{7}{|c|}{ Percentage of antibiotic resistance } \\
\hline & & GM & VA & $\mathrm{CN}$ & SXT & $\mathrm{CC}$ & CIP & $\mathrm{C}$ \\
\hline \multirow[t]{2}{*}{ S. epidermidis } & a: 523 & 36.6 & 1.0 & 19 & 62.2 & 38.1 & 21.2 & 11.8 \\
\hline & b: 1295 & 46.7 & 1.3 & 21 & 60 & 45 & 40.2 & 18.5 \\
\hline \multirow[t]{2}{*}{ S. aureus } & a: 132 & 30.6 & 0.0 & 25.9 & 34 & 18.5 & 20.5 & 6.8 \\
\hline & b: 250 & 33.5 & 0.0 & 27 & 31.6 & 28.5 & 22.4 & 6.6 \\
\hline \multirow[t]{2}{*}{ Entrococci Spp. } & a: 29 & 22.0 & 1.6 & ND & 50 & ND & 33.0 & ND \\
\hline & b: 115 & 73.2 & 18.5 & 70 & 76.3 & 72.4 & 56.0 & 40 \\
\hline \multirow[t]{2}{*}{ Streptococcus viridans } & a: 34 & 79.0 & 3.0 & ND & ND & ND & 29.0 & 7 \\
\hline & b: 45 & 80.4 & 5.8 & 15.1 & 63.7 & 28.7 & 30.0 & 12.5 \\
\hline Streptococcus & a: 20 & 86.7 & 0.0 & 0 & 62.5 & 7.7 & 0.0 & 17.8 \\
\hline Pneumonia & b: 23 & 66.7 & 0.0 & 11.1 & 66.7 & 11.1 & 11.1 & ND \\
\hline
\end{tabular}

Abbreviations , Period a: 2001-2004; Period b: 2005-2008,: GM; gentamicin, VA; vancomycin,CN; cephalexin, SXT; co-trimoxazole, Ap; ampicillin, CC; clindamycin, CIP; ciprofloxacin, C; chloramphenicol, ND; not determined

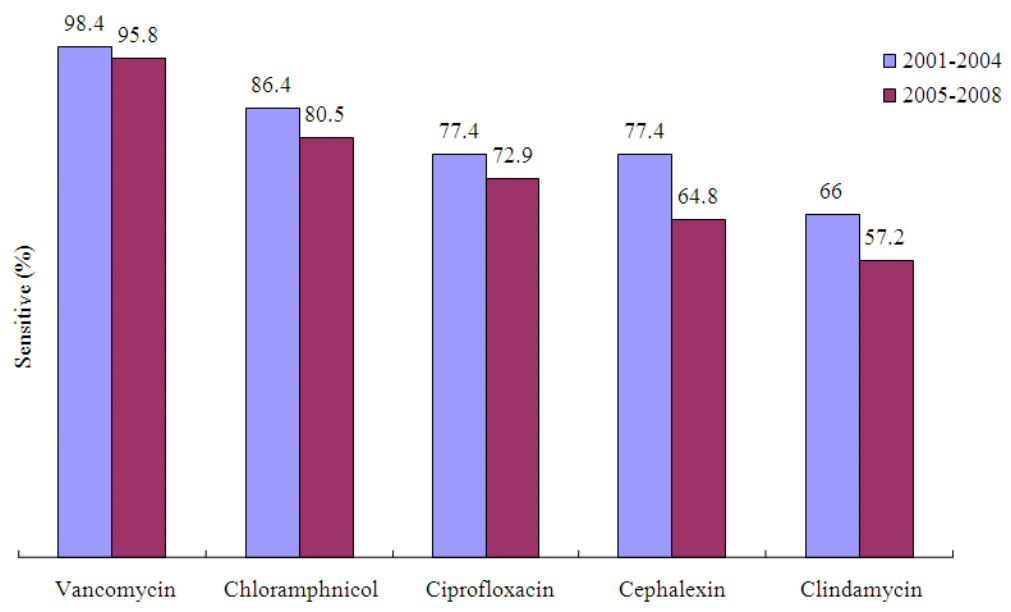

Fig. 1: Comparison of Gram positive sensitivity profiles to five effective antibiotics over the periods 2001-2004 and 2005-2008

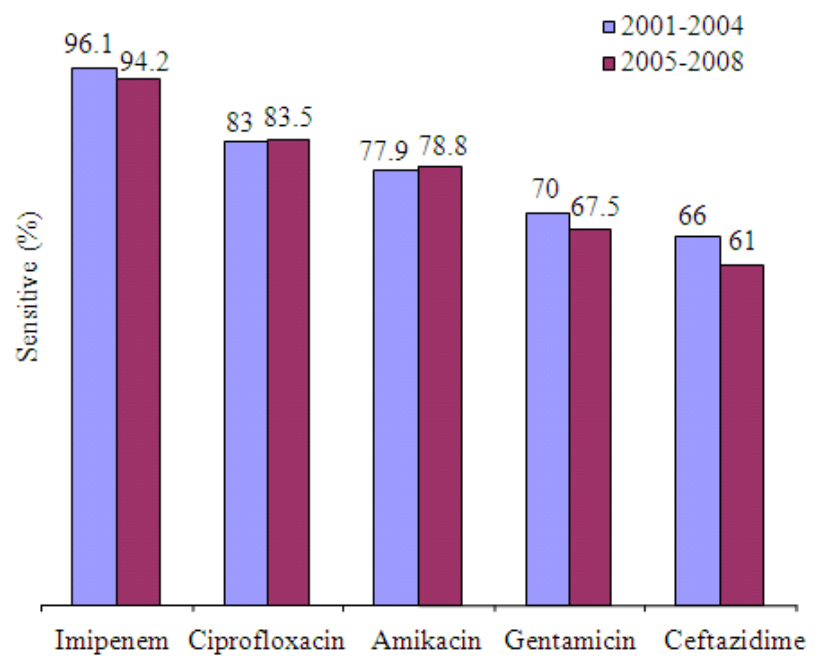

Fig. 2: Comparison of Gram negative sensitivity profiles to five effective antibiotics over the periods 2001-2004 and 2005-2008 
Am. J. Infect. Dis., 7 (1): 1-7, 2011

Table 4: Comparison of frequencies (\%) of the bacteria recovered from bactec 9240, based on hospital wards admission over the two periods (2001-2004 and 2005-2008)

\begin{tabular}{|c|c|c|c|c|c|c|c|c|}
\hline Bacteria & $\begin{array}{l}\text { Periods: a \& b: } \\
\text { Frequency (\%) }\end{array}$ & $P$ value & $\begin{array}{l}\text { Frequency (\%) } \\
\text { in neonate ward }\end{array}$ & $P$ value & $\begin{array}{l}\text { Frequency (\%) } \\
\text { in pediatrics ward }\end{array}$ & $P$ value & $\begin{array}{l}\text { Frequency (\%) } \\
\text { in adult ward }\end{array}$ & P value \\
\hline *Coagulase Negative & a: $523(47)$ & 0.00000 & $80(60)$ & 0.1700 & $321(49)$ & 0.00000 & $122(36)$ & 0.2000 \\
\hline Staphylococci & b:801 (32) & & $147(18.4)$ & & $420(52.4)$ & & $234(29.2)$ & \\
\hline Staphylococcus aureus & a: 132 (12) & 0.00000 & $11(8.2)$ & $0.002 *$ & $66(10)$ & 0.00000 & $55(16.2)$ & 0.0700 \\
\hline E.coli & $\begin{array}{l}\text { a: } 64 \text { (6) } \\
\text { b:64 (2.6) }\end{array}$ & 0.00000 & $\begin{array}{l}5(4.0) \\
4(3) \\
5(7.8)\end{array}$ & $0.470^{*}$ & $\begin{array}{l}29(4.5) \\
75(39)\end{array}$ & 0.49000 & $\begin{array}{l}90(73.8) \\
31(9.1) \\
34(53.2)\end{array}$ & 0.0040 \\
\hline $\begin{array}{l}\text { Pseudomonas } \\
\text { aeruginosa }\end{array}$ & $\begin{array}{l}\text { a: } 52(4.5) \\
\text { b:28(1.12) }\end{array}$ & 0.00000 & $\begin{array}{l}4(3) \\
3(0.7)\end{array}$ & $0.210^{*}$ & $\begin{array}{l}29(4.5) \\
10(35.7)\end{array}$ & 0.00000 & $\begin{array}{l}19(5.6) \\
15(53.6)\end{array}$ & 0.0018 \\
\hline *Bacillus spp & $\begin{array}{l}\text { a: } 52(5.5) \\
\text { b:37(1.48) }\end{array}$ & 0.00000 & $\begin{array}{l}10(7.5) \\
4(10.8)\end{array}$ & $0.002 *$ & $\begin{array}{l}17(2.8) \\
23(62.2)\end{array}$ & 0.11000 & $\begin{array}{l}25(7.3) \\
10(27)\end{array}$ & 0.0000 \\
\hline Enterobacter spp. & $\begin{array}{l}\text { a: } 50(4) \\
\text { b:37(1.48) }\end{array}$ & 0.00000 & $\begin{array}{l}8(6) \\
4(10.8)\end{array}$ & $0.010^{*}$ & $\begin{array}{l}25(3.9) \\
15(40.5)\end{array}$ & 0.00000 & $\begin{array}{l}17(5) \\
18(48.7)\end{array}$ & 0.0250 \\
\hline Acinetobacter spp. & $\begin{array}{l}\text { a: } 40(3.5) \\
\text { b:89(3.56) }\end{array}$ & 0.99000 & $\begin{array}{l}1(0.7) \\
4(4.5)\end{array}$ & $1.000 *$ & $\begin{array}{l}31(4.8) \\
43(48.3)\end{array}$ & 0.04400 & $\begin{array}{l}8(2.3) \\
42(47.2)\end{array}$ & 0.0220 \\
\hline Streptococcus viridans & $\begin{array}{l}\text { a: } 34(3) \\
\text { b:45(1.8) }\end{array}$ & 0.02000 & $\begin{array}{l}2(1.4) \\
6(13.3)\end{array}$ & $1.000^{*}$ & $\begin{array}{l}30(4.6) \\
26(57.8)\end{array}$ & 0.00030 & $\begin{array}{l}2(0.7) \\
13(28.9)\end{array}$ & 0.1700 \\
\hline Enterococcus spp. & $\begin{array}{l}\text { a: } 29(2.5) \\
\text { b:71(2.84) }\end{array}$ & 0.67000 & $\begin{array}{l}6(4.4) \\
3(4.2)\end{array}$ & $0.030 *$ & $\begin{array}{l}10(1.5) \\
22(31)\end{array}$ & 0.97000 & $\begin{array}{l}13(3.8) \\
46(64.8)\end{array}$ & 0.1400 \\
\hline Klebsiella spp. & $\begin{array}{l}\text { a : } 29(2.5) \\
\text { b:33(1.32) }\end{array}$ & 0.00700 & $\begin{array}{l}5(3.7) \\
4(12.1)\end{array}$ & $0.140^{*}$ & $\begin{array}{l}11(1.7) \\
9(27.3)\end{array}$ & 0.02000 & $\begin{array}{l}13(3.8) \\
20(60.6)\end{array}$ & 0.2900 \\
\hline Brucella spp. & $\begin{array}{l}\text { a: } 28(2.4) \\
\text { b:10(0.4) }\end{array}$ & 0.00000 & $\begin{array}{l}0 \\
0\end{array}$ & - & $\begin{array}{l}16(2.5) \\
6(60)\end{array}$ & 0.00002 & $\begin{array}{l}12(3.5) \\
4(40)\end{array}$ & $0.0003^{*}$ \\
\hline $\begin{array}{l}\text { Streptococcus } \\
\text { pneumoniae }\end{array}$ & $\begin{array}{l}\text { a: } 20(1.6) \\
\text { b:9(0.36) }\end{array}$ & 0.00000 & $\begin{array}{l}0 \\
0\end{array}$ & - & $\begin{array}{l}19(2.9) \\
9(100)\end{array}$ & 0.00002 & $\begin{array}{l}1(0.3) \\
0\end{array}$ & - \\
\hline *Diphteroid & $\begin{array}{l}\text { a: } 16(1.3) \\
\text { b:50(2) }\end{array}$ & 0.24000 & $\begin{array}{l}2(1.4) \\
4(8)\end{array}$ & $1.000 *$ & $\begin{array}{l}5(0.8) \\
26(52)\end{array}$ & 0.07000 & $\begin{array}{l}9(2.6) \\
20(40)\end{array}$ & 0.9900 \\
\hline Salmonella spp. & $\begin{array}{l}\text { a: } 11(1) \\
\text { b:5(0.2) }\end{array}$ & $0.00002 *$ & $\begin{array}{l}0 \\
0\end{array}$ & - & $\begin{array}{l}7(1) \\
2(40)\end{array}$ & $0.00200 *$ & $\begin{array}{l}4(1.2) \\
3(60)\end{array}$ & $0.2100^{*}$ \\
\hline Haemophilus influenzae. & $\begin{array}{l}\text { a: } 8(0.8) \\
\text { b:5(0.2) }\end{array}$ & $0.03000 *$ & $\begin{array}{l}0 \\
0\end{array}$ & - & $\begin{array}{l}81.2) \\
5(100)\end{array}$ & $0.00300 *$ & $\begin{array}{l}0 \\
0\end{array}$ & - \\
\hline
\end{tabular}

*: Analyzed with Fisher's exact test, significant values printed in bold. Period a: 2001-2004; Period b: 2005-2008

\section{DISCUSSION}

It has been proposed that frequencies and antibacterial susceptibility patterns of nosocomial pathogens continuously change, which demands periodical surveillance of their fluctuations (Japoni et al., 2009; Sepehri et al., 2010)

In the present study, frequencies (\%) of bacteria isolated from the blood samples of patients, changed in quality and quantity from first to the second period. Continuous changing of nosocomial pathogens has been previously reported (Starnes et al., 2008). Amsterdam et al. (2010) Patients may be infected in the community and transfer these bacteria to hospitals, as happened for methicillin resistance $S$. aureus or vice versa (Song et al., 2011). Exchanging of resident flora in the hospital with circulating bacteria in the community, may gradually reduce the efficacy of the prescribed antibiotics in outpatients and render them ineffective (Zhang et al. 2010; Moskowitz et al., 2010). Nevertheless, this flow does not reduce the nosocomial resistance rate due to continuous emerging of resistant isolates which may happen under selective pressure of consuming antibiotics in the hospitals (Ozer et al., 2011).
Increased frequencies of some antibiotic resistant bacteria such as acinetobacter and entrococci, have been observed from first to second periods, which demands appropriate attention and action to be taken. Change in the ecology of nosocomial bacteria from antibiotic sensitive to antibiotic resistant bacteria may revert by frequent application of strong antiseptics and disinfectants along with strong control measures ( Sepehri et al., 2009); Special attention should be taken to educate personnel for frequent hand washing, correct using of gloves to prevent cross-contamination of other patients, wearing gown and mask (Sepehri et al., 2009).and preventing of close contact of patients admitted to infectious wards with visitors (Xerry et al., 2010). Of course, hospital personnel are more important in cross-contamination of patients. Therefore, routine surveillance of personnel of the hospitals and suspending from duty the healthy carrier individuals, carrying antibiotic resistant bacteria such as Methicillin Resistant S. aureus (MRSA), Vancomycin Resistance Entrococci (VRE) and pseudomonas until they become decontaminated, might prove effective (March et al., 2010; Askarian et al., 2009). The data also support the hypothesis that determination of antibiotic sensitivity patterns in periodic intervals should be 
mandatory in each region, for choosing appropriate antibiotic therapy (Japoni et al., 2009; Sepehri et al., 2010).

The number of positive cultures in the pediatric ward was high, compared with adults and neonates wards. This is partly due to the number of beds in pediatrics ward which admit a wide range of patients with ages ranging from 6 months to 16 years old. Moreover, children at pre or primary school ages may have not received appropriate hygienic cares, as compared with adults. Besides, neonates' hygiene is continuously supported and monitored by their mothers.

Overall efficacy of antibiotics reduced in the second study period (2005-8). Continuous prescription of antibiotics in hospitals and clinics can give rise to the emerging antibiotic resistance due to clonal selection (Velickovic-Radovanovic et al., 2011). It is documented that due to continuous emerging of resistant isolates, the efficacy of antibiotics decreases gradually, particularly those administrated for bloodstream infections (Amsterdam et al., 2010) Bakowski et al., 2008)However, in the present study, in vitro efficacy of two antibiotics (ciprofloxacin and amikacin) preserved. Present results show that imipenem and vancomycin are highly active against Gram negative and positive bacteria. These results are in concordance with other reports However, it should not be expected that this activity continues for a longtime, as it has been observed during this study and reports from other centers (Jamal et al. 2010; Grant et al., 2010). Nevertheless, ciprofloxacin and chloramphenicol are alternative antibiotics with lower efficacies.

\section{CONCLUSION}

Present findings reveal the etiology of infectious diseases of the blood over two periods. The recovered bacteria with high frequency from blood samples at pediatrics ward indicates that special attention should be paid to such wards both in prevention and treatment aspects. Vancomycin and imipenem were the most active antibiotics which could cover the majority of Gram positive and negative bacteria. Therefore, an administration of the combination of these two antibiotics is highly recommended for empirical therapy. To maintain the efficacy of a few effective antibiotics, strict control measures should be implemented.

\section{ACKNOWLEDGMENT}

We appreciate $H$. Khajehei for his valuable linguistic copy editing.

\section{REFRENCES}

Amsterdam, D., G. Coombs and M. Dowzicky, 2010. Antimicrobial susceptibility of bloodstream isolates of staphylococcus aureus: Global results from the tigecycline evaluation and surveillance trial, 2004-2008. Am. J. Infect. Dis., 6: 1-7. DOI: 10.3844/ajidsp.2010.1.7

Askarian, M., A. Zeinalzadeh, A. Japoni, A. Alborzi and Z.A. Memish, 2009. Prevalence of nasal carriage of methicillin-resistant Staphylococcus aureus and its antibiotic susceptibility pattern in healthcare workers at Namazi Hospital, Shiraz, Iran. Int. J. Infect. Dis., 13: e241-e247. DOI: 10.1016/j.ijid.2008.11.026

Bakowski, E., S.B. Wey and E.A. Servolo, 2008. Risk factors for bacteremia and predictors of mortality of patients with bloodstream infection with methicillin-resistant staphylococcus aureus. Am J. Infect. $\quad$ Dis., 4: 262-266. DOI: 10.3844/ajidsp..2008.262.266

Bert, F., B. Larroque ,C. Paugam-Burtz , S. Janny and F. Durand et al., 2010. Microbial epidemiology and outcome of bloodstream infections in liver transplant recipients: an analysis of 259 episodes. Liver. $\quad$ Transpl., $\quad$ 16: 393-401. DOI: $10.1002 / 1 t .21991$

Cermak, P., S. Cermakova, A. Schwarzerova, M. Klementova and M. Ulrychova et al., 2011 The potential use of blood culture systems for diagnosing intravascular catheter-related infections. Clin. Lab., 57: 13-20. PMID: 21391460

Grant, D.G., T.T. Zhang, L. S. Gloyne, A. V. Perkins and M.J. Kiefel et al., 2010. Exogenous pyocyanin alters pseudomonas aeruginosa susceptibility to ciprofloxacin. Am. J. Microb., 1: 9-13. DOI: 10.3844/ajmsp.2010.9.13

Jamal, W., M. Shahin and V.O. Orotimi, 2010. Surveillance and trends of antimicrobial resistance among clinical isolates of anaerobes in Kuwait hospitals from 2002 to 2007. Anaerobe., 16: 1-5. DOI: 10.1016/j.anaerobe.2009.04.004

Japoni, A., A. Vazin, M. Hamedi, M.A. Davarpanah and A. Alborzi et al., 2009. Multidrug-resistant bacteria isolated from intensive-care-unit patient samples. Braz. J. Infect. Dis. DOI: 10.1590/S141386702009000200009

Kim, K.E. and J.Y. Han, 2010. Evaluation of the clinical performance of an automated procalcitonin assay for the quantitative detection of bloodstream infection. Korean. J. La. Med., 30: 153-159. DOI: 10.3343/kjlm.2010.30.2.153 
March, A., R. Aschbacher, H. Dhanji, D.M. Livermore and A. Bottcher et al., 2010. Colonization of residents and staff of a long-term-care facility and adjacent acute-care hospital geriatric unit by multiresistant bacteria. Clin. Microbiol. Infect., 16: 934-944. DOI: 10.1111/j.1469-0691.2009.03024.x

Moskowitz, S.M., W. Kronish and P.C. Jeanine, 2010. Mechanisms of bacterial virulence in pulmonary infections. Curr. Opin. Crit. Care., 16: 8-12. DOI: 10.1097/MCC.0b013e3283354710

Ozer, B., B.C.O. Akkurt, N. Duran, Y. Onlen and L. Savas et al., 2011. Evaluation of nosocomial infections and risk factors in critically ill patients. Med Sci.Monit., 17: 17-22. PMID: 21358613

Paolucci, M., M.P. Landini and V. Sambri, 2010. Conventional and molecular techniques for the early diagnosis of bacteraemia. Int. J. Antimicrob. Agents, 36: S6-S16. 10.1016/j.ijantimicag.2010.11.010

Sepehri, G., H.Z. Nejad, E. Sepehri and S. Razban, 2010. Bacterial Profile and Antimicrobial Resistance to commonly used antimicrobials in intra-abdominal infections in two teaching hospitals. Am. J. Applied Sci, 7: 38-43. DOI: 10.3844/ajassp.2010.38.43

Sepehri, G., N. Talebizadeh , A. Mirzazadeh, T.R. Mirshekari and E. Sepehri, 2009. Bacterial contamination and resistance to commonly used antimicrobials of healthcare workers' mobile phones in teaching hospitals, Kerman, Iran. Am J. Applied Sci., 6: 806-810. DOI: 10.3844/ajassp.2009.806.810
Song, J.H., P.R. Hsueh, D.R. Chung, K.S. Ko and C.I. Kang et al., 2011. Spread of methicillin-resistant Staphylococcus aureus between the community and the hospitals in Asian countries: An ANSORP study. J Antimicrob. Chemother., 66: 1061-1069. DOI: $10.1093 / \mathrm{jac} / \mathrm{dkr} 024$

Starnes, M.J., C.V.R. Brown, I.R. Morales, P. Hadjizacharia and A. Salim et al., 2008. Evolving pathogens in the surgical intensive care unit: a 6year experience. J. Crit. Care, 23: 507-12. DOI: 10.1016/j.jcrc.2008.02.007

Velickovic-Radovanovic, R., J. Petrovic, B. Kocic, S. Antic and R. Mitic, 2011. Analysis of antibiotic utilization and bacterial resistance changes in a surgical clinic of clinical centre, Nis. J Clin. Pharm. Ther. DOI: $10.1111 / \mathrm{j} .1365-$ 2710.2010.01241.x

Xerry, J., C.I. Gallimore, D. Cubitt and J.J. Gray, 2010. Tracking environmental norovirus contamination in a pediatric primary immunodeficiency unit. J. Clin. Microbiol., 48: 2552-2556. DOI: 10.1128/JCM.00066-10

Zhang, W., Y. Gu,Y. Chen, H. Deng and L. Chen et al., 2010. Intestinal flora imbalance results in altered bacterial translocation and liver function in rats with experimental cirrhosis. Eur. J. Gastroenterol. Hepatol., $\quad 22$ : 1481-1486. DOI: 10.1097/MEG.0b013e32833eb8b0 